\title{
Biological aspects of sea snakes caught incidentally by commercial trawlers off Goa, west coast of India
}

\author{
Vinay P. Padate ${ }^{1}$, Lalita V. Baragi ${ }^{2} \&$ Chandrashekher U. Rivonker $^{3}$ \\ ${ }^{1,3}$ Department of Marine Sciences, Goa University, Taleigao Plateau, Goa 403206, India \\ ${ }^{2}$ National Institute of Oceanography (CSIR), Dona Paula, Goa 403004, India \\ Email: ${ }^{1}$ vinaypp83@ rediffmail.com; ${ }^{2}$ lalita270@gmail.com; ${ }^{3}$ curivonker@ gmail.com (corresponding author)
}

Date of publication (online): 26 December 2009 Date of publication (print): 26 December 2009 ISSN 0974-7907 (online) | 0974-7893 (print)

Editor: Ted J. Wassenberg

\section{Manuscript details:}

Ms \# 02253

Received 07 July 2009

Final received 25 November 2009

Finally accepted 27 November 2009

Citation: Padate, V.P., L.V. Baragi \& C.U. Rivonker (2009). Biological aspects of sea snakes caught incidentally by commercial trawlers off Goa, west coast of India. Journal of Threatened Taxa 1(12): 609-616.

Copyright: @ $\odot$ Vinay P. Padate, Lalita V. Baragi \& Chandrashekher U. Rivonker 2009. Creative Commons Attribution 3.0 Unported License. JoTT allows unrestricted use of this article in any medium for non-profit purposes, reproduction and distribution by providing adequate credit to the authors and the source of publication.

Author Details: VINAY P. PADATE obtained his MSc degree in Marine Sciences from Goa University in 2005 and is currently working as Research Assistant at the Department of Marine Sciences, Goa University. He is engaged in studying taxonomy and community structure of demersal marine fauna along the coasts of Goa and Visakhapatnam, India. LALITA V. BARAGI obtained her MSc degree in Marine Sciences from Goa University in 2008 and is currently working as Project Assistant at the Marine Corrosion and Materials Research Division, National Institute of Oceanography, Dona Paula, Goa. She is engaged in studying bio-fouling organisms, particularly barnacles. Dr. ChandRashekher U. RivonkER obtained PhD in Marine Sciences in 1992 from Goa University and has about 22 publications in referred journals. Presently Associate Professor, he is working in the area of Demersal fish diversity.

Author Contribution: VPP carried out sampling for the study along the potential fishing grounds off Goa, followed by taxonomic identification of sea snakes and their seasonal distribution. LVB carried out the biological analyses including gut content analysis, reproduction and symbiotic associations. CUR planned, designed and participated in the field work and was instrumental in interpretation and discussion of the manuscript.

Acknowledgement: See end of this article.
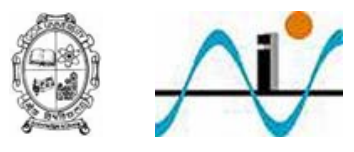

Abstract: Sea snakes occur in trawl hauls as by-catch, incurring mortality in populations inhabiting commercial fishing grounds ( $<20 \mathrm{~m}$ depth) along the coastal inshore waters of Goa. Observations of this incidental catch show that true sea snakes inhabiting inshore waters comprise two species: Enhydrina schistosa and Lapemis curtus, contributing 65 and $35 \%$ of the population respectively. 70 trawl operations over a period of 17 months with a total fishing effort of 110 hours yielded 43 individuals, all females, which numerically contributed $\sim 1 \%$ to the total trawl catch. Seasonal variations indicate that there is an increasing trend in abundance from postmonsoon to pre-monsoon season. The capture of a gravid female from the estuarine inshore waters during January suggests parturition and recruitment among sea snakes during the postmonsoon season. An assessment of the food composition in the stomach content revealed completely digested prey in smaller individuals, whereas in larger-sized individuals these items were either undigested or semi-digested. Qualitative assessment of gut content of sea snakes revealed the dominance of finfish (Ariidae, Engraulidae, Clupeidae). A biological assessment of a gravid female and the association of sea snakes with a barnacle species (Octolasmis grayii) are described.

Keywords: Sea snakes, Goa, trawl, seasonal variations, biological aspects.

\section{InTRODUCTION}

Coastal ecosystems exhibit high variability in ecological parameters that are largely influenced by land use patterns and runoff, resulting in seasonal anomalies. The prevalence of a wide range of abiotic factors provides an array of habitats for opportunistic marine species that move between coastal and estuarine environments, thus providing enormous scope for increased diversity (Ansari et al. 1995; Venkataraman \& Wafar 2005). Among these areas, commercial fishing grounds are of great concern as they are subjected to indiscriminate removal of non-target species (Kumar \& Deepthi 2006) as by-catch, including sea snakes. Sea snakes inhabit shallow estuarine waters and coral reefs throughout the Indo-Pacific region (Burns \& Heatwole 1998; Heatwole 1999). Sixty-two species have been recorded so far, and approximately $60 \%$ of these are known to inhabit Australian territorial waters (Heatwole 1999). Indian waters are known to harbour about 25 species, with the report of 11 species from the Gulf of Mannar (Karthikeyan et al. 2008) and two along the West coast (Lobo et al. 2004). Although sea snakes are commercially exploited for various applications in the Philippines, Australia, Japan, Taiwan and Thailand (Rasmussen 2001), in other coastal areas they are considered nuisance species.

Sea snakes show seasonal movement between inshore and offshore waters either in search of food or for bearing young (Shuntov 1971; Wassenberg et al. 1994). Fry et al. (2001) suggested that the females of most species appear to be gravid in the summer, and presumably bear young towards the end of this period in Australian waters.

Sea snakes form an important constituent in the marine environment as they occupy a high position in the food web, feeding upon various finfish and invertebrate species (Glodek \& Voris 1982; Heatwole 1999). In addition, sea snakes interact with other marine organisms through symbiotic interactions. For example, sea snakes are reported to be fouled by barnacles (Reynolds \& Pickwell 1984) and other marine organisms (Dunson 1975; Zann et al. 1975). The present paper addresses the taxonomic composition of the assemblage of true sea snake species, seasonal variations in trawl catches and certain biological attributes such as feeding habits, reproduction and symbiotic associations, based on observations made using commercial trawlers along the fishing grounds of Goa. 


\section{Materials and Methods}

Study area: The coastal waters of Goa are flanked by six estuaries, the Mandovi-Zuari estuarine complex $\left(15^{\circ} 25^{\prime}-\right.$ $15^{\circ} 31^{\prime} \mathrm{N} \& 73^{\circ} 45^{\prime}-73^{\circ} 59^{\prime} \mathrm{E}$, Fig. 1) being the most prominent ecosystem in terms of productivity and species diversity, possibly due to regular tidal inundation (pers. obs.) in spite of the influence of anthropogenic input. During the South-west monsoon, fresh water influx becomes a major factor that controls the hydrodynamics of this estuarine complex, whereas tides play an important role during other periods. The bathymetry of this estuarine complex indicates silt, clay and detritus transported by riverine influx from the upper reaches where mangrove vegetation occurs in high density, making for a highly productive detritus-based food chain (Kulkarni et al. 2003 ) with highly diversified biota. The study area encompasses the fishing grounds $<20 \mathrm{~m}$ depth that are subjected to increasing levels of exploitation by commercial trawl operations.

Sampling strategy: During the study period (February 2006 to February 2008) a total of 70 trawl operations $(110 \mathrm{~h}$ fishing effort) were undertaken onboard commercial trawlers in the estuarine and inshore waters of Goa, west coast of India (Fig. 1) to assess the diversity and total community structure of the demersal fauna. Twenty trawl operations were once a month (during January to April 2006, October 2006, and January 2008) and 50 were undertaken on fortnightly basis (during December 2006 to May 2007, November 2007, and February 2008). Sixteen trawling operations were undertaken in the Mandovi-Zuari estuarine complex (six in Zuari Estuary, two each in Aguada and Mormugao bays, three each in Mandovi Estuary and Cumbharjua Canal) during September and October 2006, and May, September and December 2007 and January 2008. Trawl nets with mesh sizes of $15 \mathrm{~mm}$ (mouth end) and $9 \mathrm{~mm}$ (cod end) were towed at a speed of approximately 2 knots $\left(4 \mathrm{~km} \mathrm{~h}^{-1}\right)$. The catch obtained was sorted into five sub-samples. Uncommon (or rare) specimens including sea snakes were picked out, put on ice and sent to the laboratory for detailed examination. In addition, samples were obtained by operating

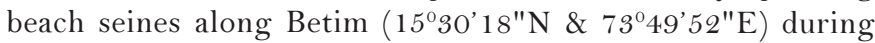
December, 2005 and twice in the vicinity of Mormugao Port Trust $\left(15^{\circ} 24^{\prime} 16^{\prime \prime} \mathrm{N} \& 73^{\circ} 48^{\prime} 56^{\prime \prime} \mathrm{E}\right)$ during December, 2005 and September, 2006 to assess the occurrence of demersal species in the estuarine embayment, as these were inaccessible to demersal trawlers. Sampling could not be undertaken during monsoon due to a ban on trawl operations along the Goan coast (Goa, Daman and Diu Marine Fishing Regulation Rules 1982). Voucher specimens were stored in 5\% formalin solution in transparent plastic bottles. These are deposited at the Marine Biology laboratory, Department of Marine Sciences, Goa University.

Species identification: At the laboratory, specimens were preserved using 6-8\% formalin solution and identified up to the species level by employing orthodox taxonomic methods such as morphometric and meristic characters aided by an identification key (Rasmussen 2001). Subsequently, snout-vent length and tail length (in centimetres) of each specimen were measured using measuring tape and total weight (in grams) was measured using an electronic balance (Sartorius - CP225D).

Gut content analysis and data compilation: In order to

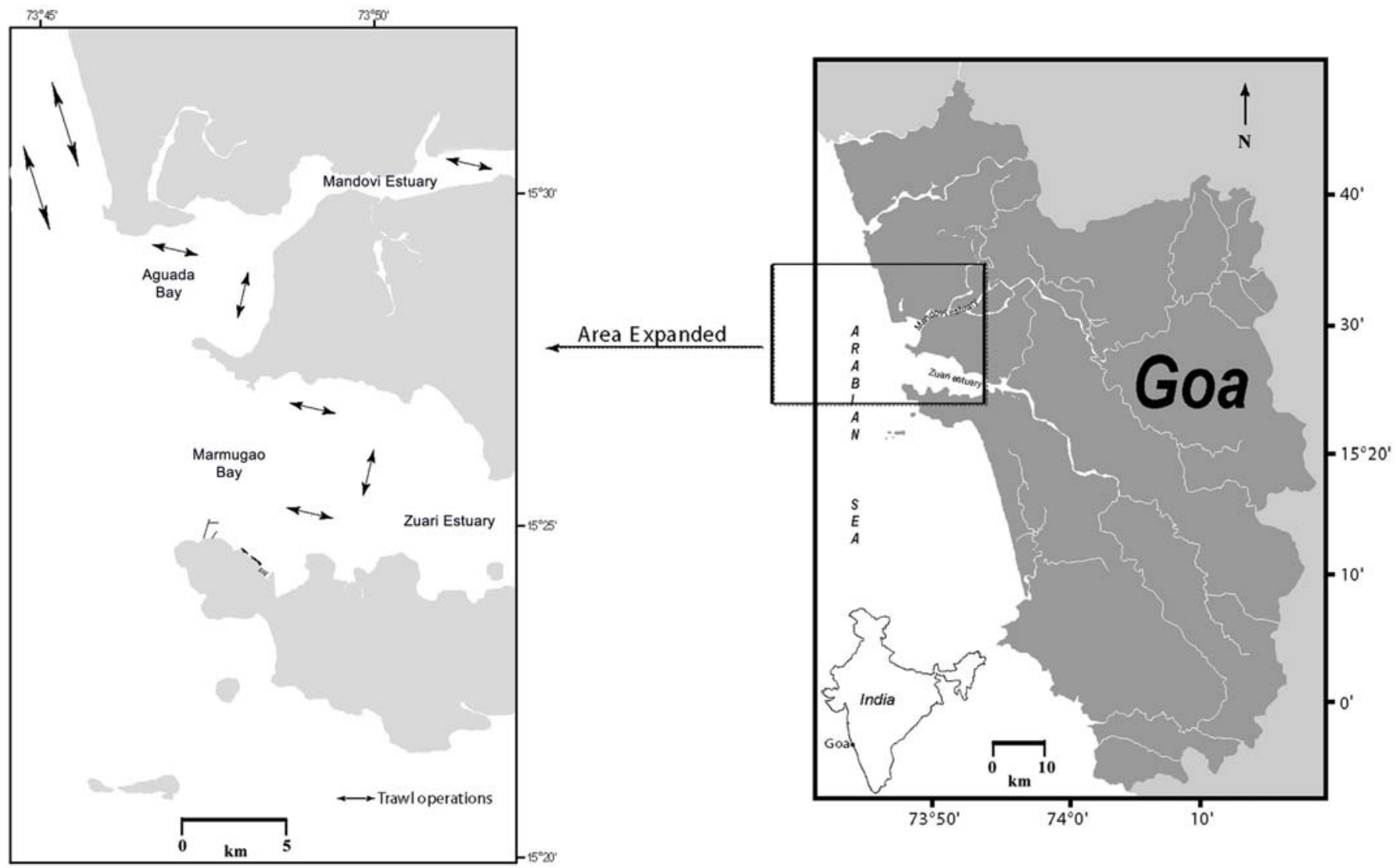

Figure 1. Map of study area indicating trawl sampling sites 

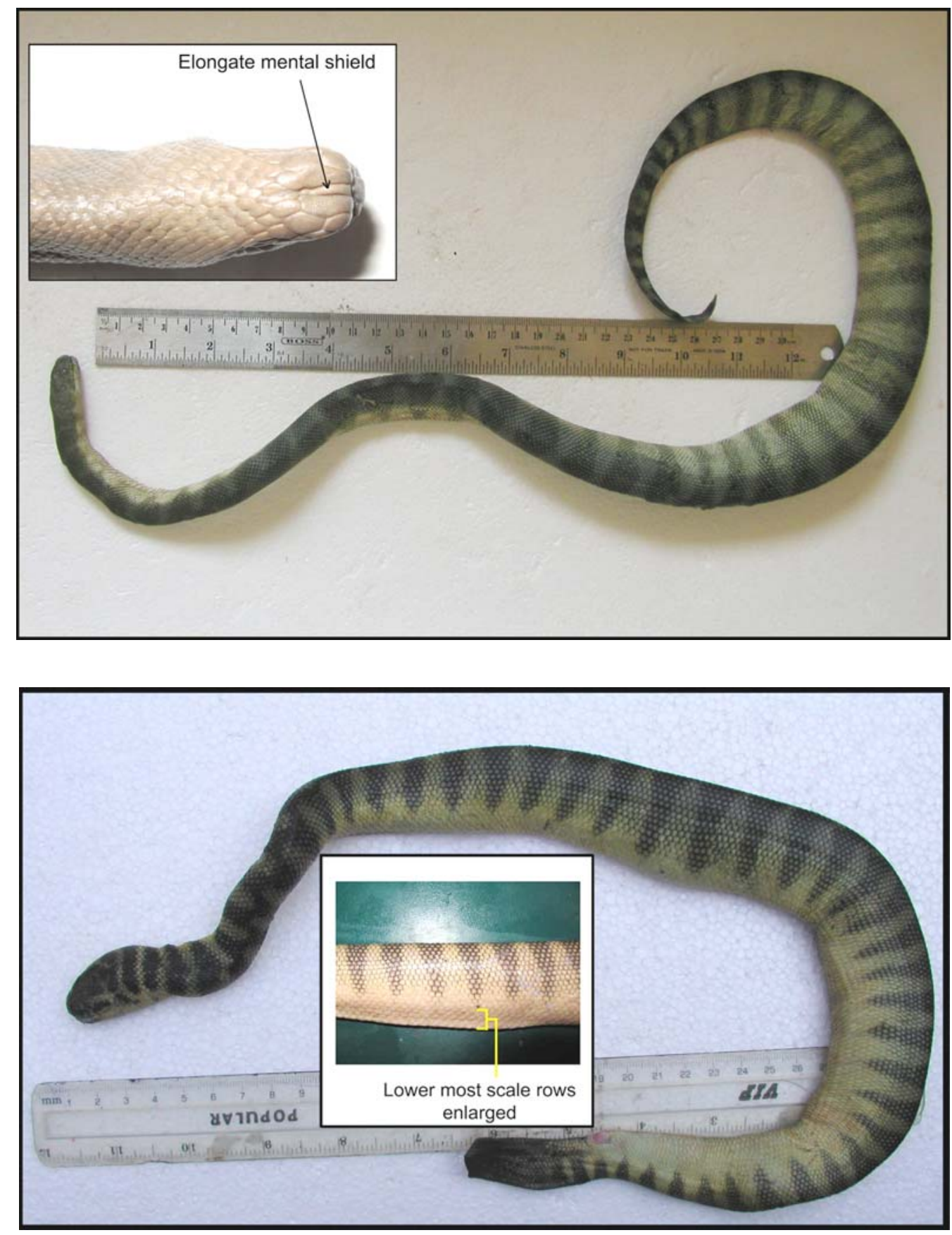

Image 1. Enhydrina

schistosa with distinguishing character (inset)

Image 2. Lapemis curtus with distinguishing character (inset) analyze dietary items of sea snakes, the specimens were first dissected to expose the gut, then the gut was divided into three parts (foregut, midgut and hindgut) and the status of food items (undigested, semi-digested or completely digested) examined. Food contents were subjected to quantitative assessment using a wet gravimetric method (Hyslop 1980). Undigested prey was identified to species level.

The data collected on sea snakes and the trawl catch composition during the study period (except monsoon) was used to describe seasonal variations. These data were assessed in terms of the number per trawl and later expressed as a percentage contribution. In addition, demersal fishes occurring in the trawl catch and those found in the gut of sea snakes were identified to species level using identification keys (Fischer \& Whitehead 1974). The monthly data collected on sea snakes
Table 1. Taxonomic characters of sea snakes observed along Goa coast

\begin{tabular}{llll}
\hline & Taxonomic character & Enhydrina schistosa & Lapemis curtus \\
\hline 1. Scales around neck & $45-50$ & $25-30$ \\
2. Scale rows around body & $50-55$ & $40-42$ \\
3. Number of ventral scales & $250-270$ & $200-220$ \\
4. Distinguishing characters & Mental shield on ventral & Mental shield \\
& & margin of head & not elongated. \\
& elongated. & Lower scale \\
& All scale rows of & rows enlarged. \\
\hline
\end{tabular}

and their prey items composition within the catch was collated to respective seasons and plotted graphically.

Analysis of reproduction: In order to have an insight into 
Table 2. Details of morphometric measurements of sea snake specimens $(\mathrm{N}=43)$ collected from Goa coast along with their means and standard deviation

\begin{tabular}{|c|c|c|c|c|c|}
\hline & \multirow{3}{*}{$\begin{array}{l}\text { Morphometric } \\
\text { parameters }\end{array}$} & \multicolumn{4}{|c|}{ Species } \\
\hline & & \multicolumn{2}{|c|}{ E. schistosa } & \multicolumn{2}{|c|}{ L. curtus } \\
\hline & & Range & Mean \pm S.D. & Range & Mean \pm S.D. \\
\hline 1. & Snout-vent length $(\mathrm{cm})$ & $38.75-71.25$ & $56.34 \pm 9.57$ & $42.00-48.75$ & $45.70 \pm 2.30$ \\
\hline 2. & Tail length (cm) & $3.75-12.50$ & $7.95 \pm 2.89$ & $3.75-7.50$ & $5.30 \pm 1.05$ \\
\hline 3. & Weight (g) & $32.00-150.00$ & $98.18 \pm 37.43$ & $40.00-120.92$ & $60.05 \pm 26.19$ \\
\hline
\end{tabular}

reproductive behaviour, the sex of each specimen was determined based on anatomical features (hemipenes in males and ovaries in females). In the case of gravid females, uterine tubes containing ova were separated from the viscera and the diameter $(\mathrm{cm})$ and weight $(\mathrm{g})$ of each ovum measured using vernier callipers and an electronic balance, respectively.

Symbiotic associations: Each sea snake was observed for the presence of barnacles. These were detached from skin of the specimen using forceps, and identified to species level using the identification key provided by Fernando (2006).

\section{Results And Discussion}

Species composition, abundance and seasonal trends of sea snakes

True sea snakes (Hydrophiidae) form an important component of the coastal habitats of tropical and sub-tropical marine environments. These marine reptiles are known to occur in large numbers in the Indo-Pacific region (Heatwole 1999; Karthikeyan et al. 2008). However, published reports (Lobo et al. 2004) indicate that the species diversity among these groups decreases progressively towards the west. In the present study, sea snake samples contained only females of two species (Table 1), namely Enhydrina schistosa (Image 1) and Lapemis curtus (Image 2). The present observations suggest that the collected individuals (all females) were mainly involved in inshore estuarine migrations. Voris et al. (1978) indicated that estuaries serve as a nursery and that adults enter estuaries to bear young. Lobo et al. (2004) reported the occurrence of these two species along the Goan coast, however, no attempt was made to provide information on the systematics of these species. They further suggested that sex ratios of both the species were highly biased towards females, whereas Voris \& Jayne (1979) and Lemen \& Voris (1981) reported seasonal fluctuations in the sex ratio of sea snakes from Malaysia and suggested that this could be a function of sexual differences in habitat selection and their activity

The present observations were made over 17 months with $110 \mathrm{~h}$ fishing effort, and revealed only 43 individuals (all females), thus indicating sparse occurrence $(<1 \%$ in terms of numbers per trawl) of these species in the coastal fishing grounds (Table 2). Such observations also indicate that sea snakes are subsidiary and non-target organisms occurring in the trawl catches (pers. obs.). Further, occurrence of these species in low numbers in the trawl catch could be attributed to several factors such as low reproductive rate (Voris \& Jayne 1979; Lemen \& Voris 1981; Heatwole 1997), high rate of infertility (Lemen \& Voris 1981), high mortality rate up to $45.8 \%$ among neonates and survival rates as low as $6 \%$ among potentially reproducing females (Voris \& Jayne 1979). Moreover, factors such as restricted spatial distribution in

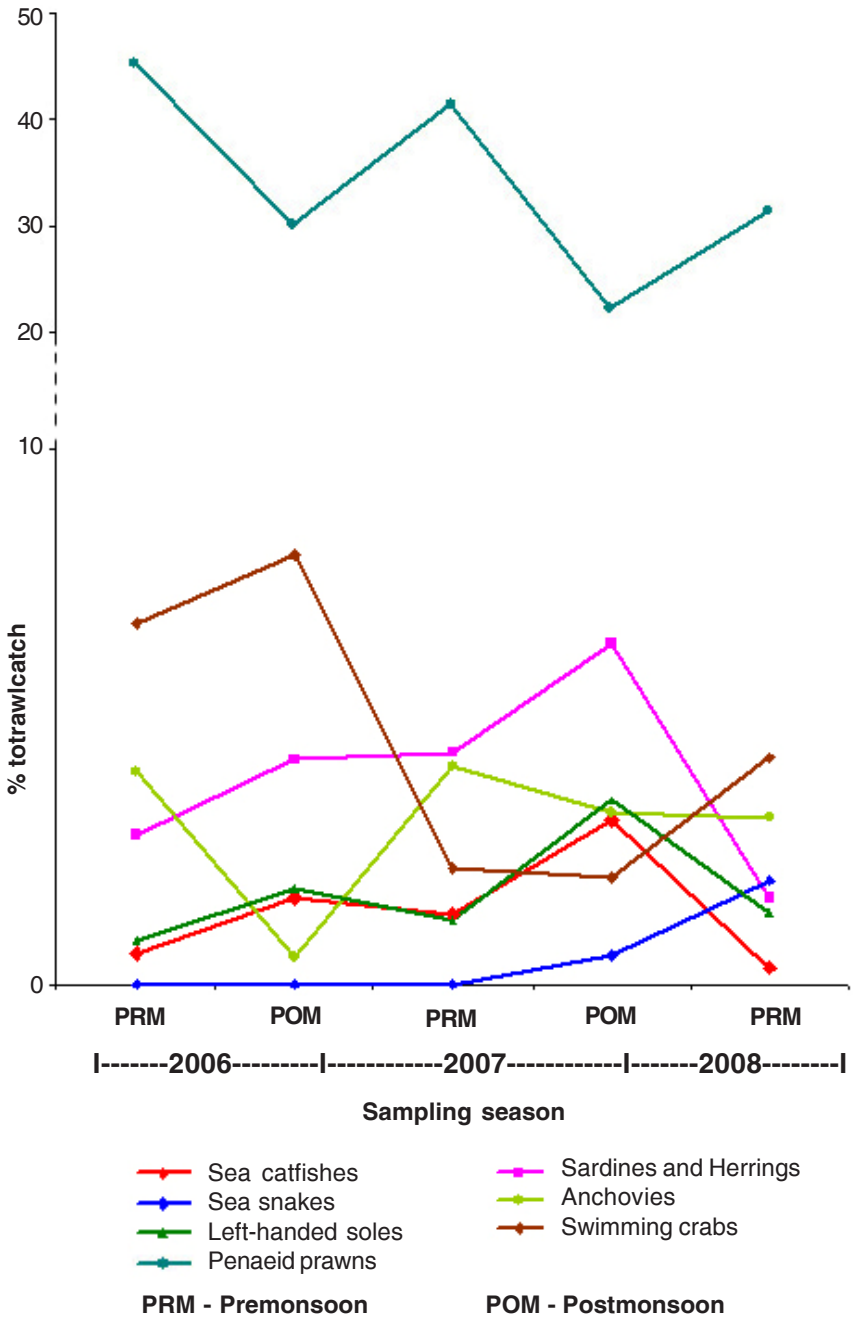

Figure 2. Seasonal variations in percentage contribution of sea snakes and their prey items to total trawl catch

estuaries and shallow coastal reefs (Rasmussen 2001) due to water circulation and abundance of prey (Shuntov 1971), high level of targeted fishing as well as growing incidents of their incidental capture in prawn fishing grounds (Wassenberg et al. 1994) might also augment to their occurrence in low numbers. Among the sea snakes caught during the present study, $E$. schistosa $(>65 \%)$ dominated the trawl catch as compared to $L$. curtus (<35\%). However, Tu (1974) and Wassenberg et al. (1994) reported that L. hardwickii (L. curtus) contributes to about $81-88 \%$ and $53 \%$ of all the sea snakes caught in the coastal waters of Thailand and Gulf of Carpentaria, Australia, respectively.

The numerical data collected during trawl fishing was grouped under four major categories (teleosts, crustaceans, 
TROPHIC LEVEL

PELAGIC
ENVIRONMENT
BENTHO-PELAGIC ENVIRONMENT
BENTHIC ENVIRONMENT

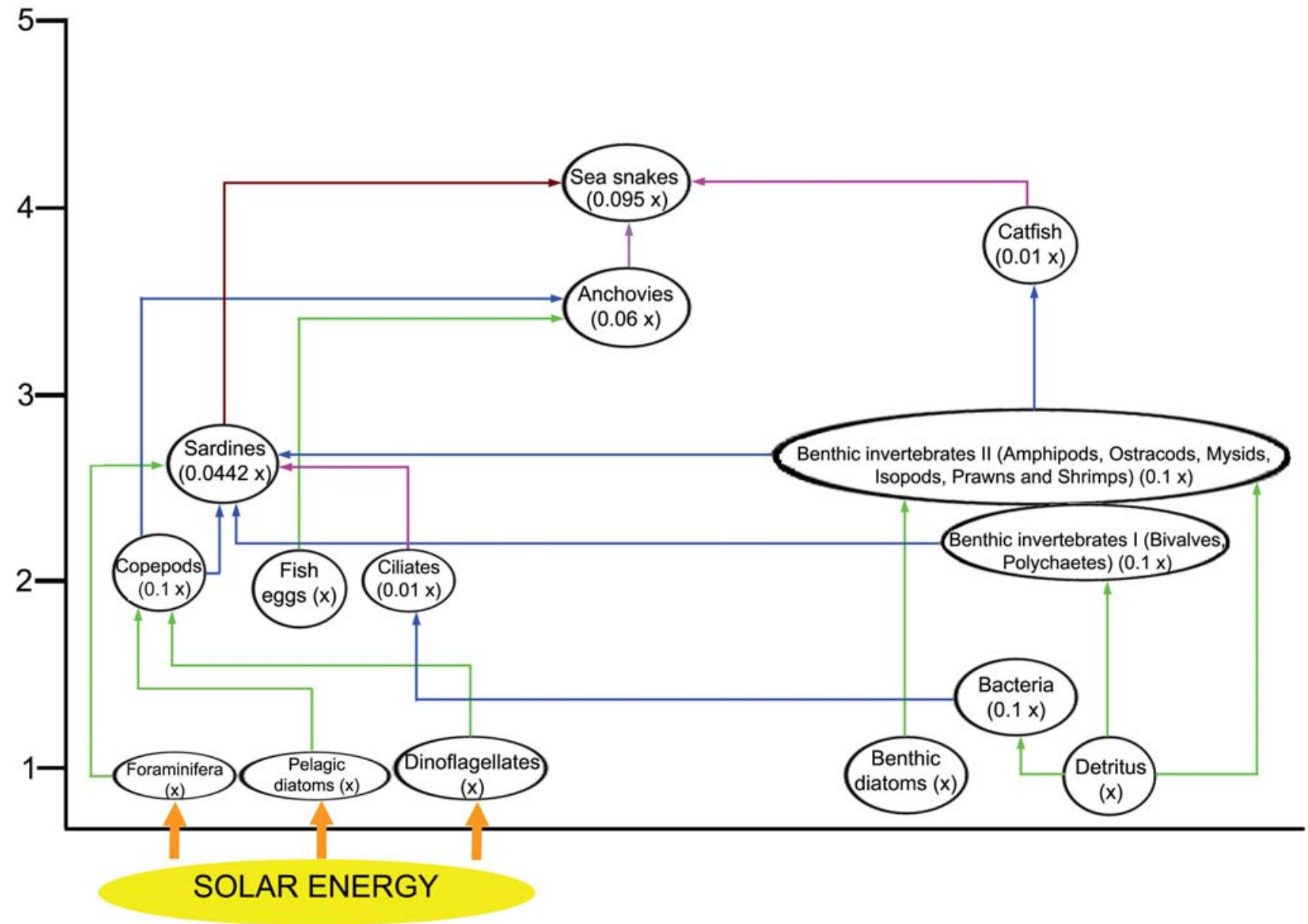

Figure 3. Flow chart depicting hypothetical food chain and energy flow of sea snakes

Table 3. Month wise percentage of sea snakes and their dietary items in the trawl catches of Goan coast

\begin{tabular}{|c|c|c|c|c|c|c|c|c|c|c|c|c|c|}
\hline \multirow[t]{2}{*}{ Faunal group } & \multicolumn{2}{|c|}{$\begin{array}{l}\text { PRM } \\
2006\end{array}$} & \multicolumn{3}{|c|}{$\begin{array}{l}\text { POM } \\
2006-07\end{array}$} & \multicolumn{3}{|c|}{$\begin{array}{l}\text { PRM } \\
2007\end{array}$} & \multirow[b]{2}{*}{ M } & \multicolumn{3}{|c|}{$\begin{array}{c}\text { POM } \\
2007-08\end{array}$} & \multirow{2}{*}{$\begin{array}{l}\text { PRM } \\
2008 \\
F^{2}\end{array}$} \\
\hline & $\mathbf{F}$ & M & A & D & J & $\mathbf{F}$ & M & A & & $\mathbf{N}$ & D & $J$ & \\
\hline Sea snakes & 0.00 & 0.02 & 0.01 & 0.00 & 0.01 & 0.03 & 0.01 & 0.01 & 0.00 & 0.55 & 0.00 & 0.66 & 1.93 \\
\hline Sea catfishes & 0.25 & 0.46 & 1.00 & 0.00 & 2.79 & 0.98 & 1.04 & 0.49 & 2.34 & 1.07 & 1.10 & 5.46 & 0.32 \\
\hline Anchovies & 7.84 & 1.29 & 2.17 & 0.29 & 0.65 & 2.68 & 2.35 & 7.00 & 3.42 & 1.65 & 0.56 & 5.29 & 3.12 \\
\hline Sardines and Herrings & 1.27 & 2.17 & 4.77 & 7.61 & 1.78 & 6.78 & 3.14 & 5.56 & 2.23 & 4.57 & 8.97 & 7.63 & 1.61 \\
\hline Croakers & 0.59 & 1.68 & 2.81 & 1.22 & 4.73 & 5.11 & 6.95 & 2.84 & 1.29 & 2.68 & 2.38 & 4.81 & 2.92 \\
\hline Left-handed Soles & 1.40 & 0.67 & 0.41 & 3.48 & 0.58 & 1.27 & 2.77 & 0.44 & 1.05 & 6.09 & 0.00 & 1.48 & 1.35 \\
\hline Swimming Crabs & 15.04 & 2.94 & 1.30 & 1.61 & 12.61 & 3.92 & 2.97 & 1.96 & 0.77 & 3.19 & 2.07 & 0.84 & 4.25 \\
\hline Penaeid Prawns & 22.31 & 64.13 & 54.30 & 27.36 & 32.01 & 31.87 & 28.88 & 42.48 & 53.41 & 29.26 & 31.64 & 13.27 & 31.38 \\
\hline
\end{tabular}

PRM - Pre-monsoon (February to May); POM - Post-monsoon (November to January)

molluscs and sea snakes) indicating maximum ( $63 \%)$ contribution from crustaceans, followed by teleosts $(\sim 35 \%)$, whereas molluscs and sea snakes contribute much less $(\sim 1 \%)$ each.

The seasonal variations in the percentage of sea snakes in the trawl catches reveal that the contribution of sea snakes increased from December to February (post-monsoon; Table 3). This can be largely attributed to the commencement of fishing at the end of the monsoon ban and subsequent increase in number of fishing boats due to calm conditions in the sea along the Goan coast (pers. obs.). Another possible reason could be the migration of females to the inshore estuarine waters as only female individuals were captured during the present study. These include a fully gravid E. schistosa female captured from the estuarine waters at a depth of about 5-8 m. Ansari et al. $(1995,2003)$ suggest that this estuarine complex with mangrove vegetation acts as a potential nursery ground for opportunistic marine species that migrate there either for spawning or for feeding purpose. Voris (1985) reported feeding of E. schistosa juveniles on young ariid catfish in Muar Estuary, Malaysia 


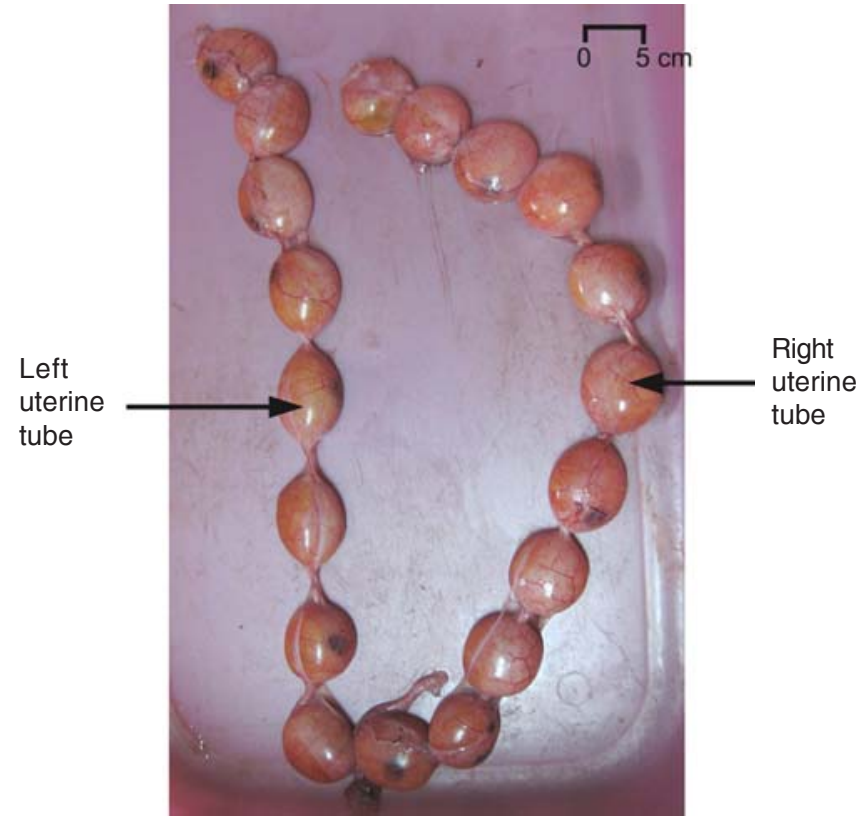

Image 3. Matured ova of Enhydrina schistosa
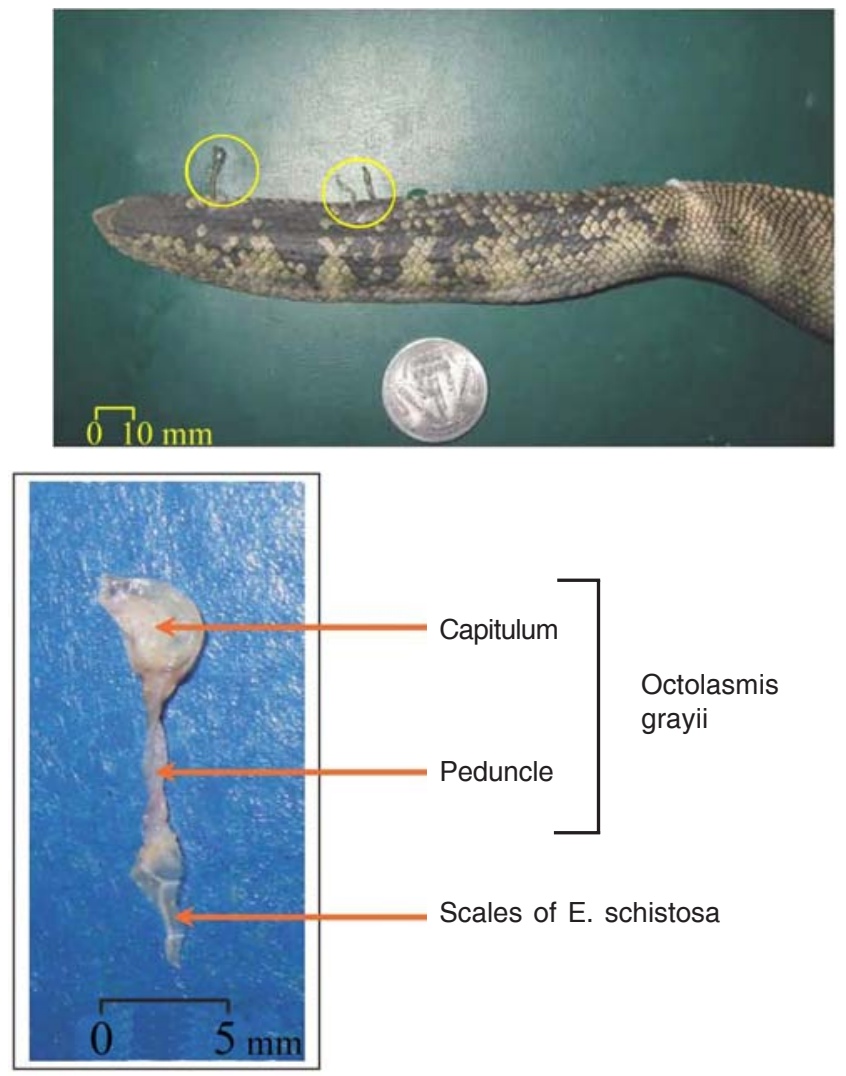

Image 4. Symbiotic association between sea snake and barnacle

(a) Epizoite pedunculate barnacle, Octolasmis grayii (encircled) on tail of sea snake, Enhydrina schistosa (b) Enlarged view of Octolasmis grayii

although they were found to be absent offshore, suggesting shoreward migration. Shuntov (1971) indicated that sea snakes were widely dispersed during winter and were concentrated
Table 4. Qualitative analysis of the gut contents of sea snakes collected in trawl catches of Goan coast

\begin{tabular}{llllcl}
\hline & $\begin{array}{c}\text { Sampling } \\
\text { Date }\end{array}$ & Species & Foregut & $\begin{array}{c}\text { Gut content } \\
\text { Midgut }\end{array}$ & Hindgut \\
\hline 1. & $27 / 3 / 2006$ & E. schistosa & $\mathrm{E}$ & $\mathrm{SD}^{\ddagger}$ & $\mathrm{CD}$ \\
2. & $27 / 3 / 2006$ & E. schistosa & $\mathrm{E}$ & $\mathrm{SD}^{\ddagger}$ & $\mathrm{CD}$ \\
3. & $27 / 3 / 2006$ & L. curtus & $\mathrm{E}$ & $\mathrm{SD}^{\ddagger}$ & $\mathrm{CD}$ \\
4. & $24 / 4 / 2006$ & E. schistosa & $\mathrm{E}$ & $\mathrm{SD}^{\ddagger}$ & $\mathrm{CD}$ \\
5. & $24 / 4 / 2006$ & E. schistosa & $\mathrm{E}$ & $\mathrm{SD}^{\ddagger}$ & $\mathrm{CD}$ \\
6. & $6 / 1 / 2007$ & E. schistosa & $\mathrm{E}$ & $\mathrm{SD}^{\ddagger}$ & $\mathrm{CD}$ \\
7. & $6 / 1 / 2007$ & L. curtus & $\mathrm{E}$ & $\mathrm{SD}^{\ddagger}$ & $\mathrm{CD}$ \\
8. & $26 / 1 / 2007$ & E. schistosa & $\mathrm{E}$ & $\mathrm{SD}^{\ddagger}$ & $\mathrm{CD}$ \\
9. & $3 / 2 / 2007$ & L. curtus & $\mathrm{E}$ & $\mathrm{SD}^{\ddagger}$ & $\mathrm{CD}$ \\
10. & $19 / 2 / 2007$ & E. schistosa & $\mathrm{E}$ & $\mathrm{SD}^{\ddagger}$ & $\mathrm{CD}$ \\
11. & $11 / 3 / 2007$ & E. schistosa & $\mathrm{E}$ & $\mathrm{SD}^{\ddagger}$ & $\mathrm{CD}$ \\
12. & $25 / 3 / 2007$ & L. curtus & $\mathrm{E}$ & $\mathrm{SD}^{\ddagger}$ & $\mathrm{CD}$ \\
13. & $11 / 4 / 2007$ & L. curtus & $\mathrm{E}$ & $\mathrm{SD}^{\ddagger}$ & $\mathrm{CD}$ \\
14. & $3 / 11 / 2007$ & E. schistosa & $\mathrm{E}$ & $\mathrm{SD}^{\ddagger}$ & $\mathrm{CD}$ \\
15. & $30 / 11 / 2007$ & E. schistosa & $\mathrm{E}$ & $\mathrm{SD}^{\ddagger}$ & $\mathrm{CD}$ \\
16. & $9 / 1 / 2008$ & E. schistosa & $\mathrm{E}$ & $\mathrm{SD}^{\ddagger}$ & $\mathrm{CD}$ \\
17. & $29 / 1 / 2008$ & E. schistosa & $\mathrm{E}$ & $\mathrm{SD}^{\ddagger}$ & $\mathrm{CD}$ \\
18. & $10 / 2 / 2008$ & L. curtus & $\mathrm{E}$ & $\mathrm{SD}^{\ddagger}$ & $\mathrm{CD}$ \\
\hline
\end{tabular}

E - Empty; SD - Semi-digested; CD - Completely digested

${ }^{\ddagger}$ - Arius jella; ${ }^{*}$ - Thryssa dussumieri; ${ }^{*}$ - Unidentified clupeiform fish

along the estuarine regions only during spring and attributed this to seasonal changes in water currents and to abundance of fish.

Dietary composition and trophic level of sea snakes

The qualitative analysis of gut contents of sea snakes $(\mathrm{N}=$ $41)$ revealed an empty foregut in all specimens. However, the mid guts of larger individuals contained undigested ( 25\%) to semi-digested prey $(\sim 75 \%)$, whereas those of smaller individuals contained completely digested food. In addition, the hindgut of all specimens was observed to contain completely digested food.

Identification of the dietary components of sea snakes revealed two partially digested prey items namely, Arius jella (Family Ariidae) and Thryssa dussumieri (Family Engraulidae) from the mid gut of E. schistosa. Published literature on diet composition of E. schistosa (Voris et al. 1978; Voris \& Voris 1983 ) suggests that it prefers to prey upon catfish. Further, Voris et al. (1978) indicated that in addition to ariid catfish, the species also preyed upon plotosid catfish and puffers. They also suggested that factors including innate preferences, individual habits and availability of prey determined the selection of dietary items (prey) by sea snakes. However, experimental data on sea snake feeding habits (Voris et al. 1978) indicate a wide range of food items in the gut probably attributed only to prey availability. However, gut contents of L. curtus revealed an unidentified clupeiform fish in a semidigested state. Glodek \& Voris (1982) and Lobo et al. (2005) indicate that L. curtus is a generalist feeder known to prey upon more than eight different fish families from different depths.

Further, comparison of the seasonal trends of capture of sea snakes in trawl catches (Table 3) with those of the prey organisms in the trawl catches revealed an inverse relationship with prey organisms such as catfishes (Family Ariidae), anchovies (Family Engraulidae), and clupeids (Family Clupeidae), therefore suggesting that high numbers of sea snakes had a marked effect on these groups (Fig. 2). Such observations highlight the importance of these groups as food items of the sea snakes. Voris et al. (1978) and Lobo et al. 
(2005) also indicated dominance of these items in the gut content of sea snakes. On the other hand, seasonal trends in number of sea snakes did not exhibit any particular relationship with those of other prey organisms such as portunid crabs and penaeid prawns (Fig. 2), indicating less dependence on these species as prey items.

In an attempt to focus on the niche level of sea snakes in the bentho-pelagic environment, the data collected on the sea snakes and the gut contents were carefully analyzed and presented in the form of a flow chart (Fig. 3) to hypothetically assess the trophic position of sea snakes by using a trophic scale (Pauly et al. 1998) that represents the primary constituents of the marine food web that interact among themselves through complex preypredator relationships. In this exercise it was assumed that about $90 \%$ of the energy is lost during the transfer from one trophic level to the next higher one (Odum 1959; Kozlovsky 1968), with exception of certain groups like sardines and anchovies that are involved in complex interactions at different trophic levels. In such cases, the energy values were derived by obtaining means of the above constituents involved in distinct food chains. The occurrence of sea snakes in the benthopelagic habitat coupled with their carnivorous feeding habit indicates that they act as top predators in the community, feeding mainly on nektonic populations. Voris (1972) suggested that sea snakes use a wide range of food types and opined that the data collected on the diet of sea snakes could be used to construct a qualitative picture of the possible role of sea snakes in trophic dynamics.

\section{Spawning}

Our observations on the spawning of sea snakes were primarily based on dissection of individuals $(\mathrm{N}=41)$ to expose their reproductive systems. Among the dissected individuals one E. schitosa female, captured from the estuarine waters at 5$8 \mathrm{~m}$ depth, contained $19 \mathrm{eggs}$ (11 in the right and eight in the left uterine tube) (Image 3). The means and standard deviation for diameter and weight $(\mathrm{N}=19)$ of her ova were found to be $4.20 \pm 0.05 \mathrm{~cm}$ and $14.09 \pm 1.00 \mathrm{~g}$, respectively. Voris and Jayne (1979) stated that sea snakes give birth to offspring during the post-monsoon season in the inshore waters of Malaysia and further suggested that clutch size increases with the size of the female and can reach thirty or more. However, Karthikeyan et al. (2008) reported a maximum of three to five clutches in Hydrophis cyanocintus females and opined that clutch size increases with the size of the females in this species.

\section{Symbiotic associations}

Sea snakes $(\mathrm{N}=5)$ were associated with barnacles (Image 4a), a constituent of inter-tidal rocky zones and which have a cementing gland for attachment. In the present study, these individuals were found to be attached to the surface of the sea snakes. These barnacles were identified as Octolasmis grayii (Image $4 \mathrm{~b}$ ). This is the first report of such an association among sea snakes and barnacles from the tropical inshore waters of Goa. Although, Jeffries \& Voris (1996) remarked that different types of symbiotic associations prevail among marine organisms, there are no specific studies that elucidate the nature of this association. The present observations suggest that it could be parasitic, as the stalked barnacle (Octolasmis grayii), attach to these reptiles following shedding of the skin, primarily on large-sized individuals and they get detached before subsequent shedding of the skin. The observations made in the present study emphasize the need for further investigations of the mode of attachment and the nature of interactions.

\section{Why study sea snake ecology?}

The data obtained in the present study indicate that approximately two snakes are incidentally trapped per trawl haul. Although, this figure appears to be small, if one computes the cumulative effect of such undesirable removal ever since the mechanization of fishing craft and trawling gear along the Goan coast since 1963, it appears that such action can create significant changes in the benthic coastal environment. In India, sea snakes are protected under Section IV of the Wildlife (Protection) Act, 1972. However, prevention and control of unintentional trapping of sea snakes by legislation and its subsequent implementation is a difficult task owing to the lack of appropriate infrastructure and monitoring mechanisms along such an extensive coastline. Further, there is a dearth of management strategies such as use of exclusion devices to avoid entry of sea snakes in the trawl net. In light of the above, the present study attempts to elucidate the ecological significance of these organisms in the coastal marine environment and recommends strict enforcement of legislation and adoption of appropriate management practices to avoid removal of sea snakes.

Review of sea snake ecology from the Indian waters reveals that available information is poor and scanty. Therefore, a holistic approach to investigate the ecology of sea snakes may be a useful tool to bring about improved understanding and enable development of effective conservation and management plans.

\section{References}

Ansari, Z.A., A. Chatterji, B.S. Ingole, R.A. Sreepada, C.U. Rivonker \& A.H. Parulekar (1995). Community structure and seasonal variation of an inshore demersal fish community at Goa, West Coast of India. Estuarine, Coastal and Shelf Science 41: 593-610.

Ansari, Z.A., R.A. Sreepada, S.G. Dalal, B.S. Ingole \& A. Chatterji (2003). Environmental influences on the trawl catches in a bay estuarine system of Goa. Estuarine, Coastal and Shelf Science 56: 503515.

Burns, G., \& H. Heatwole (1998). Home range and habitat use of the Olive Sea Snake, Aipysurus laevis, on the Great Barrier Reef, Australia. Journal of Herpetology 32: 350-358.

Dunson, W.A. (1975). Adaptation of sea snakes, pp. 3-19. In: Dunson, W.A. (ed.). The Biology of Sea Snakes. University Park Press, Baltimore, $\mathrm{xi}+530 \mathrm{pp}$.

Fernando, S.A. (2006). Monograph on Indian barnacles - Marine Benthos 02. Ocean Science and Technology Cell, Cochin University of Science and Technology, Kochi, 199pp.

Fischer, W., \& P.J.P. Whitehead (1974). FAO Species Identification Sheets for Fishery Purposes. Eastern Indian Ocean (fishing area 57) and Western Central Pacific (fishing area 71) Volume I-IV. Food and Agricultural Organization, Rome.

Fry, G.C., D.A. Milton \& T.J. Wassenberg (2001). The reproductive biology and diet of seasnake by-catch of prawn trawling in northern Australia: characteristics important for assessing the impact on population. Pacific Conservation Biology 7: 55-73.

Glodek, G.S. \& H.K. Voris (1982). Marine snake diets: prey composition, diversity and overlap. Copeia 1982: 661-666.

Goa, Daman and Diu Marine Fishing Regulation Rules (1982). Notification 2-2-81 - FSH. Governement of Goa, Daman and Diu, Forest and Agriculture Dept, Panaji, Goa, India.

Heatwole, H. (1997). Marine snakes: are they a sustainable resource? 
Wildlife Society Bulletin 25: 766 - 772.

Heatwole, H. (1999). Sea Snakes. University of New South Wales Press Limited, Sydney, 148pp.

Hyslop, E.J. (1980). Stomach contents analysis - a review of methods and their application. Journal of Fish Biology 17: 411-429.

Jeffries, W.B. \& H.K. Voris (1996). A subject-indexed bibliography of the symbiotic barnacles of the genus Octolasmis grayii, 1825 (Crustacea: Cirripedia: Poecilasmatidae). The Raffles Bulletin of Zoology 44: 575-592.

Karthikeyan, R., S. Vijayalaksmi \& T. Balasubramanian (2008). Feeding and parturition of female annulated sea snake Hydrophis cyanocinctus in captivity. Current Science 94: 660-664.

Kozlovsky, D.G. (1968). A critical evaluation of the trophic level concept. I. Ecological efficiencies. Ecology 49: 48-60.

Kulkarni, S.S., C.U. Rivonker \& U.M.X. Sangodkar (2003). Role of meiobenthic assemblages in detritus based food chain from estuarine environment of Goa. Indian Journal of Fisheries 50: 465-471.

Kumar, A.B. \& G.R. Deepthi (2006). Trawling and by-catch implications on marine ecosystem. Current Science 90: 922-931.

Lemen, C.A. \& H.K. Voris (1981). A comparison of reproductive strategies among marine snakes. Journal of Animal Ecology 50: 89-101.

Lobo, A.S., B. Pandav \& K. Vasudevan (2004). Weight-length relationships in two species of marine snakes along the coast of Goa, Western India. Hamadryad 29: 89-93.

Lobo, A.S., K. Vasudevan \& B. Pandav (2005). Trophic ecology of Lapemis curtus (Hydrophiinae) along the Western Coast of India. Copeia 2005: 636-640.

Odum, E.P. (1959). Fundamentals of Ecology. 2nd edition. Saunders, Philadelphia, 546pp.

Pauly, D., V. Christensen, J. Dalsgaard, R. Froese \& J.F. Torres (1998). Fishing down marine food webs. Science 279: 860-863.

Rasmussen, A.R. (2001). Sea Snakes, pp. 3987-4008. In: Carpenter, K.E. \& V.H. Niem (eds.). FAO species identification guide for fishery purposes. The living marine resources of the Western Central Pacific. Volume 6. Food and Agricultural Organization, Rome.

Reynolds, R.P. \& G.V. Pickwell (1984). Records of the yellow-bellied sea snake, Pelamis platurus, from the Galapagos Islands. Copeia 1984: 786-789.

Shuntov, V.P. (1971). Sea snakes of the north Australian shelf (in Russian). Ekologiya 2: 65-72.

Tu, A.T. (1974). Sea snake investigation in the Gulf of Thailand. Journal of Herpetology 8: 201210.

Venkataraman, K. \& M. Wafar (2005). Coastal and Marine biodiversity of India. Indian Journal of Marine Sciences 34: 57-75.

Voris, H.K. (1972). The role of sea snakes (Hydrophiidae) in the trophic structure of coastal ocean communities. Journal of the Marine Biological Association of India 14: 429-442.

Voris, H.K. (1985). Population size estimates for a marine snake (Enhydrina schistosa) in Malaysia. Copeia 1985: 955-961.

Voris, H.K. \& B.C. Jayne (1979). Growth, reproduction and population structure of a marine snake, Enhydrina schistosa (Hydrophiidae). Copeia 1979: 307-318.

Voris, H.K. \& H.H. Voris (1983). Feeding strategies in marine snakes: an analysis of evolutionary, morphological, behavioral and ecological relationships. American Zoologist 23: 411-425.

Voris, H.K., H.H. Voris \& C.B. Liat (1978). The food and feeding behavior of a marine snake, Enhydrina schistosa (Hydrophiidae). Copeia 1978: 134-146.

Wassenberg, T.J., J.P. Salini, H. Heatwole \& J.D. Kerr (1994). Incidental capture of sea snakes (Hydrophiidae) by prawn trawlers in the Gulf of Carpentaria, Australia. Australian Journal of Marine and Freshwater Research 45: 429-443.

Zann, L.P., R.J. Cuffy \& C. Kropach (1975). Fouling organisms and Parasites associated with the skin of sea snakes, pp. 251-265. In: Dunson, W.A. (ed.). The Biology of Sea Snakes. University Park Press, Baltimore, xi+530pp.
Acknowledgements: The authors take this opportunity to express their gratitude to the Ballast Water Management Programme, India executed by National Institute of Oceanography, Dona Paula, Goa for Directorate General of Shipping, Ministry of Shipping, Government of India. Further, we express our sincere gratitude to Dr. H. Heatwole and the anonymous referee for their constructive criticism that enabled improvement in the quality of the manuscript. We would also like to thank the trawl owners and the crew of "Jesus Bless" for permitting us to carry out on-board sample collection. 